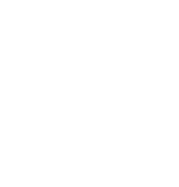

\title{
INGE'S THE TINY CLOSET IN GENDER PERSPECTIVE: RETAINING THE POLARISATION
}

\section{G.M. Adhyanggono'}

\begin{abstract}
This article is an overview toward a play of an American dramatist, William Inge. In this case, the play is viewed from gender perspective as considered 'quite representative' to reveal what Friedan (1995) stated as polarisation of men and womten. The writer wants to depict the representation of men and women in the play as the central issue affecting the result of this analysis. In addition, the term gender should be understood as an umbrella term pervading the whole discussion. To what extent the verification of the polarisation may analytically come as the conclusion.
\end{abstract}

Key words : American dramatist, gender, polarisation

\section{INTRODUCTION}

In the first place the writer needs to admit that this article is inspired by the interest of the writer upon the current women's movement roaring worldwide. Their movements seem to be more concerned with how to construct and define their existence - not as Woolf's the 'Other' (as quoted in Sheldon \& Widdowson, 1993) but as part of human race. The culturally established concepts of men and women with their social, political and economical consequences have brought about an almost endless history of women's suffering. Women become the oppressed and men are the oppressors. This vision needs to be changed. Realising that biologically we (men and women) are different - no more- but we are still human race, Friedan in her article entitled Beyond Gender (1995) has significantly emphasised the notion of mutual understanding and recognition between men and women as the following.

1. GM. Adhyanggono, SS. is a lecturer of the Faculty of Letters, Soegijapranata Catholic University, Semarang 


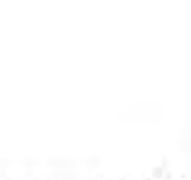

Our job now is to move beyond polarisation to a vision of community that can unite us as descent people. Are women strong enough to join or even lead men in finding that new vision? We won't stop talking about human values. But women, after all, cannot hold up more than half the sky.(1995: p.3)

From the quotation above, it is obvious that the focus of the movement (not only women's) is to build or shape a new paradigm setting itself free from the polarisation, the traditional images of men and women. Furthermore, Friedan points out that the danger of countering the hatred of women with the hatred of men (1995:p.2) will be considered contra-productive since it will entrapped us into the polarisation with a new oppressor. Thus, it is the idea of equality based on the need for redefining their relationship that becomes the very heart of this study.

In the second place, it needs to be understood that the writer does realise his sex as a man in positioning himself in this approach. To what extent this recognition may influence the analysis can be reflected in the result. It is something inevilable. In addition, if we refer to what Ecker stated in her Feminist Aesthetics (as extracted in Humm,1992:p.360) that is truly gendered perspective would mean that the sex-male or female- of both the artist and the critic is taken into account, then this recognition re-strengthened the use of gender perspective in this article.

In the third place, this study proposes a definition of gender among many others. The term gender is defined as culturally shaped group of attributes and behavior given to the female or to the male (Humm.1992:p.406). Further the theoretical ground of gender is based on what Melani Budianta wrote in her article entitled Sastra dan Ideologi Gender (1998). It is stated that there are three basic concepts or principles of gender, namely: 1) anti biological determinism, 2) relational, and 3 ) multidimensional.

\section{METHOD OF STUDY}

Deconstruction in this article is predominantly becoming the tool used. That the process or the analysis as well as the result are to be consciously perceived inevitable and need not be argued since there is no clear-cut between them. Both deconstruction and gender study try to destabilise the establised opposition in many aspects. Thus it is considered that 


\section{G.M. Adhyanggono, Inge's The Tiny Closed in Gender Persp:}

deconstruction can provide more questions on gendered prot Perpustakan Unika mentioned for the topic of this study.

Durant and Fabb in their Literary Studies in Action (1996) have described deconstruction as an attempt or approach that intends to show how one pole of Saussure's binary opposition is valued more than the other and consequently how the 'valued more' is culturally privileged and believed whereas the other is suppressed and denied. Moreover, it seeks to subvert the tendency of exalting the privileged one in the oppositions by pointing out how it relies for its meaning on its opposite (the suppressed).

Deconstruction destabilises the special meaning and value invested in the favoured term in each case, by forcing on people who establish the special value of a term the recognition that it cannot be defined apart from its related, and undesirable, negative pole.(1996:p.42)

The method of deconstructing is applicable to all text. Green and Le Bihan (1996:215) support this idea and point out that the applicability of deconstruction lies in the strength and the complexity of its philosophical base. The idea of all text includes various kinds of texts ranging from nonfiction to fiction, autograph to a poster advertisement and ever a radio program or silent movie. Hence, it is also applicable for this study.

\section{SYNOPSIS}

The story of the play takes place somewhere in Midwestern City of the United States. It is not clearly stated where it is. There are four characters involved namely; Mr. Newbold (the roomer or the guest), Mrs. Crosby (the landlady), Mrs. Hergesheimer (Mrs. Crosby's friend) and Elsie (Mrs. Crosby's servant). Yet, from the dialogue it can be inferred that it is probably set in the mid twentieth century. The play is basically staged in Mrs. Crosby's house since it is not divided into scenes or acts. Thus, Inge's The Tiny Closet is typically a short and continued-form drama.

The story begins when Mr. Newbold, living in Mrs. Crosby's house, feels that someone has tried to get closer even enter a small closet he also rents. He considers that the closet is a very private place to him so that no one could easily break into it. Yet, realising that someone has already monkeyed with the lock of the door. He is very disappointed and angry. He asks Mrs. Crosby as his landlady to mark his order to keep away anyone trying to go upstairs. 
Mrs. Crosby as the landlady feels that she has already derpustakan Unika she could. Nevertheless, in order to please her roomer she agrees to carry out the order more strictly. She promises Mr. Newbold not to let Elsie, her servant, go upstairs for any purpose. Mrs. Crosby asks him not to worry much about it. Then, he goes to work. When he gets out, Mrs. Crosby looks so nervous and excited. She childishly looks out of the window to make sure that he has already gone. Then, she orders Elsie to keep on working in the kitchen and calls her friend, Mrs. Hergesheimer. While phoning, she reveals her very feeling toward Mr. Newbold. She thinks that he is so mysterious and arrogant. It is reflected in his very manner that according to Mrs. Crosby is so 'starchy'. Further, She is very curious about the closet. She wants to find out what inside it in case that he hides something from everybody. Mrs. Crosby asks Mrs. Hergesheimer to come and fulfill their curiosity.

When Mrs. Hergesheimer comes, Mrs, Crosby decides to break into the closet and see the secret as they ever tried before. She insists Mrs. Hergesheimer to accompany her. By the time they go upstairs, Elsie comes out of the kitchen and just smiles on what the two women are doing. Then, she comes back into the room.

Unexpectedly, Mrs. Newbold sneaks into the house. He has already felt that it must be the 'insiders' who once did it and he wants to prove it. When he hears the women go down stairs, he hides in the other closet of the room. He is extremely nervous and ashamed that what he's been hiding from will be revealed. What the women have found is so weird. They find dozens of women hats inside the closet. They do not believe it but it happens. Mrs. Crosby's sentiment toward Mr. Newbold is getting more and more. She concludes that it is he who makes the hats; and it is hard to accept. She thinks it is very unusual for a man to make hats, women hats precisely, and hide them in the closet. She gets angry with him and decides to ask him to leave the house. Mrs. Hergesheimer disagrees with her but she insists it. It is very hard to believe, very unnatural that a man would do such a thing. She even burlesques the hat before a mirror and throws it onto the chair. He knows it.

As Mrs. Hergesheimer goes home and Mrs. Crosby goes to the kitchen, he comes out of his hiding place and feels so upset. His pride has gone; his starchy manner perishes. He stands still looking at the hat lying on the chair. For a while he keeps on standing and then, takes the hat with tears running 
down his cheek. Mr. Newbold slowly regains his courage. The last thing he does is heading to the kitchen and calls for Mrs. Crosby with a threatening agonised self-pride.

\section{CHARACTERISATION}

Dealing with how men and women are pictured in the play will inevitably bring us to the description of all characters. In then first place, it is better to have a description of which Mr. Newbold is. Mr. Newbold is depicted as a man of about fifty. He is large and rather nice looking. He always wears conservative clothes with dark blue suit, white shirt and modest tie. He has got thin hair upon which it is carefully combed. Mr. Newbold likes to have his black shoes shiny. He is typically who takes great pride in his appearance (Curry, 1985:20). In the play Mr. Newbold functions as the protagonist since he is the one who struggles for not being interfered to defend what is right to him. Further, he is a very starchy person both in manner and principle, One of the examples to depict his starchiness can be seen in a dialogue between him and Mrs. Crosby.

Mrs. Crosby : Do you suppose someone could got up there when no one was around and.

Mr. Newbold : I'm sure I don't know, but I won't stand for anyone's monkeying with that lock, Mrs. Crosby. That room, while I rent it, is my private property, and I gave strict instructions that no one was to go near the closet, and I expect my orders to be respected. (p.21)

There are two other characters that may also provide descriptions on Mr. Newbold. Mrs. Crosby may describe him as a self-centered person. The depiction of being so can be observed in the following dialogue as she is phoning Mrs. Hergesheimer.

Mrs. Crosby : Mrs. Hergesheimer? Have you got a minute? He's just left. "You're not to go into my room,"he says to me again, for the two hundredth time. "Someone's been playing with the lock on my door, and you're not to go near that closet," he says, like it was his house and he was ordering me about. Love letters? But why he needs a whole closet for his love letters? - If he's got any. Besides, I don't think he's type of man that has love letters. (p.23) 
In addition, Mrs. Hergesheimer describes Mr. Newbold as a haughty individual. This clue may be depicted as she is shopping at Baumgarden's.

Mrs. Hergesheimer : I made a point of talking to him when I was shopping in Baumgarden's yesterday. My, he struts around that floor. You'd think he was president instead of foorwalker. I asked him where they kept the artificial flowers. I knew, but I just wanted to see if he'd recognise me. He smiled and made a lordly gesture with his hand, showin' me the way. You'd have thought he was the king of Persia, with all his fine manners. (p.24)

From the evidences we may have a description what kind of person he is. The depiction of Mr. Newbold from other character's viewpoints will significantly support the central issue on this article.

In the second place, we are going to depict Mrs. Crosby. In the play she functions as the antagonist since she is most of the time in opposition to Mr. Newbold. She always wants to interfere what becomes Mr. Newbold's affairs. Mrs. Crosby can be described as a woman. Mrs. Crosby is a woman who cannot help for not talking. Such a depiction may be portrayec in the following dialogue.

Mr. Newbold : Mrs. Crosby! (No response) Mrs. Crosby!

Mrs. Crosby : (coming from the kitchen). I was just straightening up after breakfast. I'm afraid none of guests like the new bacon I was serving. On my word it is. Every bit. I didn't buy it to bring down expenses. Not at all. It's fine bacon. Hickory smoked. Only it's the kind you slice yourself. That's why I got it. You can cut yourself a good thick slice of bacon that you can really get your teeth into, instead of that other stuff that shrivels up like tissue paper............ She is the sort of woman who continues talking until someone stops her.) (p.20)

The quotation above is quite obvious that she is fond of talking. In addition, Mrs. Crosby also likes gossiping. It can be traced, particularly, when she talks to her friend, Mrs. Hergesheimer, about what kind of person Mr. Newbold is. 


\section{G.M. Adhyanggono, Inge's The Tiny Closed in Gender Persp}

Mrs. Crosby : That's what I've been telling myself, Mrs. Herg Perpusakaan Unika I've got every right. For all I know. I may be harbouring a spy, or a criminal, or a lunatic. ..............he might have a bomb in there he meant to destroy us with. I'm not gonna set idly by while someone is plotting something. (p.24)

Another description that we can observe from her is that she likes to peach. In this case, she intends to peach against Mr. Newbold. She certainly does it on purpose, as she wants to reveal his very secret to public. This behaviour can be seen in the following dialogue.

Mrs. Crosby : I 'm going to ask him to leave.

Mrs. Hergesheimer : Oh no, Mrs. Crosby. Don't do that.

Mrs. Crosby : I am. I'm going toask him to leave. And I'm going to call the store he works at and tell them what kind of freak they have working for them. Indeed I am. (p.27)

In addition, Mrs. Crosby is also depicted as a woman who has a pride. She obviously reveals it when she and Mrs. Hergesheimer are talking about Mr. Newbold. She deliberately places herself as an individual who is proud of her national identity.

Mrs. Crosby ..I pride myself I'm real American, and I say if anyone's got any secrets he wants to keep hid, let'm come out into the open and declare himself. (p.24)

The third figure is Mrs. Crosby's friend, Mrs. Hergesheimer. Mrs. Hergesheimer is a woman who, in the play, functions the minor character or supporting character. She also likes gossiping. She might be well depicted as an individual that, to some extent, always follows blindly what other people think of. In this case she is chiefly a character who almost has no self-decision. This can be pointed out in the following.

Mrs. Crosby : I'm not going to do it if you don't come with me.

Mrs. Hergesheimer : Well...................

Mrs. Crosby : After all, you've been just as curious about this as I've been, and I think you owe it to me to come along.

Mrs. Hergesheimer : Well, if that's the way you feel about it, Mrs. Crosby, I'll come along. After all, it's not as though we were doing anything criminal. (p.25) 
34 Celt, Volume 1, Number 1, December 2001:27-43

From the above quotation, seemingly, her indecisive characteristic is due to her curiosity on Mr. Newbold. Thus, we may also infer that she likes to interfere someone else's affair.

The last character to describe is Elsie. There are not many evidences that can depict her. Nevertheless, there is a clue that may partially represent her. She could be depicted as a woman who understands her position as Mrs. Crosby's servant. In addition, it confirms her obedience to her lady.

(Slowly, cautiously, the two women go up the stairs together. The stage is emply for a few moments, and then Elsie comes in from the kitchen, looks up the stairs with curiosity. Then, as though the behaviour of the two women were too much for to understand, she shrugs her shoulders, laughs genily, and returns to the kitchen......).(p.26)

\section{THE RELATIONSHIPS AND THE POSITIONS OF THE CHARACTERS}

The play can be classified into a comedy of satire. As a fiction, it may tell us about how the middle class society represented as a group of people who are always interested in interfering someone else's affairs. To understand how it embodies the play, it is better for us to initially understand the relations and positions of the three most important figures that can be delineated in the following.

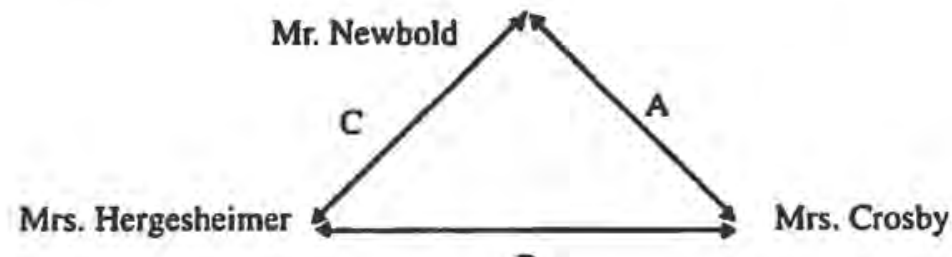

B

As touched upon, Mr. Newbold is the protagonist, Mrs. Crosby is the antagonist, and Mrs. Hergesheimer is the minor or supporting character. A represents the relationship between Mrs, Crosby and Mr. Newbold, B points out at the relationship between Mrs. Crosby and Mrs. Hergesheimer whereas $\mathrm{C}$ is between Mrs. Hergesheimer and Mr. Newbold. 
The relationship between Mrs. Crosby and Mr. Newbold is the central point to elaborate the analysis. There is, of course, a conflict, between them in which it is initially caused by their perception on the so-called 'private'. Mr. Newbold thinks that he has the right to keep his closet free from anybody. On the contrary, Mrs. Crosby thinks that she is the landlady and has every right to make sure her property is used properly. Although the conflict is not straightfoward, they both realise that they have a very touchy disagreement. This situation is likely to be 'a time bomb'. There is a statement of Mrs. Crosby that appropriately delineates such a kind of situation.

Mrs. Crosby : That's what I've been telling myself, Mrs. Hergesheimer. I've got every right. For all I know, I may be harbouring a spy, or a criminal, or a lunatic. What's he got in that closet that he don't want anyone to see? Can you tell me? It must be something he's ashamed of, or he wouldn't mind if anyone saw. Isn't that what you say? And if it's something he's ashamed of. Think we should find out what it is. You can't tell he might have a bomb in there he meant to desiray us with. I'rnot gonna set idly by while someone is plotting something. Mrs. Hergesheimer. I pride myself I'm real American, and I say if anyone's got any secrets he wants to keep hid, let'm come out into the open and declare himself. Mr. Newbold has always seemed like a fine man, and I got nothing against him personally, and he's the best roomer I ever had: keeps his room spotless. Elsie don't have to do anything but make the bed. And I appreciate that, but if you ask me, it's kind unnatural for a man to be so tidy. Isn't that what you say? There's been something suspicious about him from the very first.(p.24)

B represents the relationship between Mrs. Crosby and Mrs. Hergesheimer. They both are friends. There is no conflict between them that can be delineated in regard with the plot of the play. It can be inferred that their relationship is very closed. To Mrs. Crosby, Mrs. Hergesheimer is a friend who wants to share anything. This can be indicated when Mrs.Crosby directly calls her after Mr. New bold's leaving. On the phone they talk as if they have already got the common interest for Mr. Newbold. Thus, it can also be stated that there is almost no conflict between them. 
C. delineates the relationship between Mrs. Hergeshe Perpustakan Unika Ir. Newbold. On thing that can be inferred from their relationship is that actually they both don't have the 'real conflict'. Their conflict is quite indirect in which it is constituted under the influence of Mrs. Crosby's perspective or suspicion to him. What happens at Baumgarden's becomes the proof for Mrs. Hergesheimer to know what kind of person Mr. Newbold is. In this case, she has an opinion that he is typically an arrogant. To her, it can be indicated by the way he treats people in formal manner.

\section{DECONSTRUCTING THE TINY CLOSET}

As touched upon, the method of study used in this analysis is deconstruction. One thing to start analysing the play is by finding out the binary opposition in it. The oppositions are to be classified into two columns; favoured and not favoured. The following table shows the oppositions that exist in the play.

\begin{tabular}{|l|l|}
\hline FAVOURED & NOT-FAVOURED \\
\hline 1. landlady & 1. roomer \\
\hline 2. men & 2. women \\
\hline 3. president & 3. floorwalker \\
\hline 4. American & 4. non-American \\
\hline 5. natural & 5. unnatural \\
\hline
\end{tabular}

The left column consists of words that are privileged in the play. They are privileged because first, they are explicitly stated in the play as good or important, and second, some of them seem to be talked exclusively. The right column is for the not-favoured words. They are not privileged since some of them are meant to reveal some peculiar cases, and one of them is discussed in a footnote. (Durrant,1996:p.44)

The second step to be conducted is by drawing any resemblance of the contrasted words. First, we are going to draw the resemblance between landlady and roomer. The two words might considerably have the same underlying assumption in common. In the play, the words point out at the industrial relationship between Mrs. Crosby as the one who has the capital and Mr. Newbold as the one who rents for the capital. This owner-tenant relationship nuns a very important role for Mrs. Crosby in bringing about her curiosity and suspicion to him. Second, the contrasted men and women 


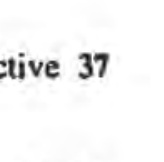

have the resemblance in which the two words refer to the culturally attributed definitions of human being based on the biological determination. Third, it is president and floorwalker to be contrasted. Linguistically, they certainly are nouns; however, they might also refer to the structurally social status or occupations. President is the head of a republic whereas floorwalker, as footnoted in the play, is department store employee who supervises sales personnel and assists customers.(Curry,1985:p.24).Fourth, American and non-American are about nationality. Fifth, natural and unnatural might be seen as etymologically the same since the later is added with prefix un-. The two words are adjectives.

The next step is trying to prove that contextually the not-favoured words are inherent in some way in the favoured ones. This can identified by deleting the not-favoured in order to verify that the favoured can to some extent stand by itself. If we delete roomer, then landlady will significantly lose its meaning in the play. Mrs. Crosby will not be described as such landlady if Mr. Newbold is not depicted as such roomer. Thus it must be there to also articulate the other. Similarly, it also occurs to men and women. When women is obscured, then there is no tendentious comparison of men and women as stated by Mrs. Crosby "Oh, men are much tidier than women, "I told her.(p.22) In this case it is quite obvious that women is used to define the significance of men in a biased perspective. Hence, men will be soundless if women are not there. Between president and floorwalker, it is also meant to be a comparison. Mrs. Hergesheimer describes Mr. Newbold's manner as if he is a president though she does not actually mean it. She thinks that as a floorwalker it is not necessary for him to behave as a president. Thus if president does not come appear, then there is no comparative emphasis she wants to reveal. Meanwhile, if not American is interpretatively articulated as a hidden meaning, then American is going to lose its exclusive value. In addition the exclusiveness of American lies on how it is described and used by Mrs. Crosby to vauntly express her being American. In this case, American is connoted as honesty and straightforwardness. Thus, to determine its 'American', it needs everything that is 'not American' as the articulator. The last is between natural and unnatural. If unnatural is obscured, then natural will not come appear as an articulated-hidden meaning. The word unnatural will only be a word that has no profound meaning in the play. Hence, one thing that can be concluded from the inherent resemblance of the words is that they exist in order to reinforce the contrast. It determines 
how they are 'politically' used to serve the favoured words Perpustakan Unika in the play.

This method is to some extent affecting the initial reading on the play. The Tiny Closet can be initially seen a comedy of satire about the middle class society at the mid of twentieth century. Yet, this method might further analyse the relationship between men and women in particular, as a representation of the traditional concepts of men and women that are still on going in the so-called modern time. After being deconstructed, then what might come appear as the central idea or theme of the play is about the social rejection to the so-called 'unusual' based on biological determination of one's choice. Regarding the positions and the relationships of the characters, it has to be understood that the theme basically emerges from the gendered bias that exists in the play. Thus, of course, there is a shift of idea from a mere comedy of satire in literature study into a gender perspective in cultural study. Nevertheless, we should not be confused with the shifting idea since this study is not meant to replace or to undermine the validity of each approach.

As we found the binary oppositions in the play, we may have landlady, men, president, American, and natural as the favoured. One thing, which is very interesting to identify, is that of the five words, four are uttered by female characters, either Mrs. Crosby or Mrs. Hergesheimer. Even natural as a hidden meaning, is implied by Mrs. Hergesheimer. This may indicate that there is tendency to use pragmatical issues to judge someone based on biological determination. To prove the indication, let's try to study the following dialogue.

Mr. Newbold : Mrs. Hergesheimer? Oh, yes, I believe I did.

Mrs. Crosby : She called me yesterday and told me she seen you. "Whata fine man that Mr.Newbold is!" she says. "You are lucky woman, Mrs. Crosby, to have such a fine guest. All I gol in my house is a lotta old-maid schoolteachers, and I'm always cleanin' up after 'em. "That' what she says. "Oh, men are much tidier than women," I told her. I kept schoolteachers once, and they was always in the bathroom. curling their hair in there or giving themselves shampoos, or shaving their legs on my nice bedspreads. Mr. Crosby was alive then, and it almost drove him crazy. He never could get to the bathroom when he wanted to, because of them schoolteachers. (p.22) 
From the dialogue above, we may have a picture of how she compares men and women in such away just to define Mr. Newbold's coyness. The way she describes how men are tidier than women is by giving an example of what old-maid schoolteachers usually do. Old-maid schoolteachers are those who like to get themselves busy with curling and shampooing their hair in the bathroom, or shaving their legs on the bed, What Mrs. Crosby wants to say is that only women do it all and not men like Mr. Newbold. It is quite obvious that this touches the gender bias. Apart from her real interest whether cynical or not, she has already placed and pictured women in that way.

Further evidence of how the 'nature' of women is revealed can be found in the following.

Mrs. Crosby : That's what I've been telling myself, Mrs, Hergesheimer. I've got every right. For all I know, I may be harbouring a spy, or a criminal, or a lunatic. What's he got in that closet that he don't want anyone to see? Can you tell me? It must be something he's ashamed of, or he wouldn't mind if anyone saw. Isn't that what you say? And if it's something he's ashamed of, I think we should find out what it is. You can't tell + he might have a bomb in there he meant to destroy us with. I' $m$ not gonna set idly by while someone is plotting something, Mrs. Hergesheimer. I pride myself I' $m$ a real American, and I say if anyone's got any secrets he wants to keep hid, let'm come out into the open and declare himself. Mr. Newbold has always seemed like a fine man, and I got nothin' against him personally, and he 's the best roomer I ever had; keeps his room spotless. Elsie don't have to do anything but make the bed. And I appreciate that, but if you ask me, it's kinda unnatural for man to be so tidy. Isn't that what you say? There's been something suspicious about him from the very first. (24)

From the above quotation, it can be deduced how Mrs. Crosby, is depicted as a woman who likes to intercede someone else's affairs. This may bring about a basic question; is it only typically woman? It is indeed arguable. Man may have the same urge as well, if it is seen as an urge. In addition, we should consider the position of Mrs. Crosby at the time in which she is the landlady and bragging herself as American. Thus, regarding all of 
these, it cannot be seen as a gender bias. Yet, an important clue that can be drawn lies at the end of her statement. She states that man is not supposed to be so tidy, and it is unnatural if he really is. Hence, there is a judgement of men and women based on biological determination that relies much on the traditional image about the characteristics of both sexes. Traditionally, men tend to be messy whereas women tend to be tidy. Thus, if any of them breaks the image, then it has to be seen as something unnatural.

Mrs. Crosby : I would. I'd rather be harboring a Communist than a man who makes hats.

Mrs. Hergesheimer: Why, there's nothing wrong with making hats. I don't see anything wrong with it. Why, lots of men make hats. Some of the finest designers there are men why, of course.

Mrs. Crosby : But he kept them locked in his closet. He was ashamed of them. (p.27)

Unlike the previous evidences, the above dialogue indicates that there is a different perception between Mrs. Hergesheimer and Mrs. Crosby about Mr. Newbold. Aftet they find out what in the closet, Hergesheimer thinks that there is nothing wrong for a man making hats. She even gives evidence that some well-known designers are men. Yet, Crosby argues that he keeps them in the closet. She thinks he does not want anybody to see them, as he is ashamed of what he has done. Further, what can be deduced from the above dialogue is that there is no agreement between Mrs. Crosby's statement and her argument. Her statement is about her disagreement about a man who makes hats. Yet, when she is asked by Mrs. Hergesheimer to give the reason, the only answer she can make is that because $\mathrm{Mr}$. Newbold keeps them in the closet. Thus, it is very illogical, and it may also be perceived as gender bias.

A more intense and obvious description of Mrs. Crosby's disagreement and rejection to $\mathrm{Mr}$. Newbold can be delineated in the following dialogue.

Mrs. Crosby, I am. I'm going to ask him to leave. And I'm going to call the store he works at and tell them what kind of freak they have working for them. Indeed I am.

Mrs. Hergesheimer: Oh, I wouldn't do that. It's not against the law for a man to make hats. He hasn't done anything really wrong. 
Mrs. Crosby : Why, a man who'd make hats and lock them up in nis closet, there is no telling what kind of person he is. He might do any kind of dangerous, crazy thing.

Mrs. Hergesheimer: Oh, I don't think so, Mrs. Crosby. Really I don't.

Mrs. Crosby : l'd rather he was a Communist. At least you know what a Communist is up to. But a man that makes hats! What can you tell about such a creature? (p.27-28)

One thing that can be inferred from the above excerpt is that there is reemphasis on her hatred or disagreement to him, which indirectly shows her real position to the concept of Anti Biological determinism. It means that her truly attitude is rejecting the equality of men and women in particular term. The experience of $\mathrm{Mr}$. Newbold to do as what women do, in this case making hats, is seen as deviation of the social norms.

Butler ever stated in her Gender Trouble (1990) as extracted in www.theory,org.uk Resources: Judith Butler that lo some extent women and men can say that feel more or less 'like a woman' or 'like a man'. In addition, it is culturally considered as an achievement to more honestly identify them in social structure that exists. Referring to it, what he does by making hats is a process of identifying and defining him as a free individual. This is what Mrs. Crosby denies because she extremely sticks on the old images about men and women. In gender study, she can be seen as a representation or a symbol of those who still keep the oid values. Unlike her, Mrs. Hergesheimer may be symbolised as those who are moderate, the ones who recognise the changes of perception between men and women within society, but still hesitate to join in.

Further, we may observe on the relational aspects of the play. As touched upon, what makes the play interesting is about Mr. Newbold's experience. When he has chosen to make hats, there is a reaction from Mrs. Crosby. First and foremost is about making the hats, and second is about keeping them in the closet. These are what she objects. It is interesting for us to know that apart from his position as the protagonist, Mr. Newbold may be contextually perceived as a biologically-defined man but has certain uniqueness that is making hats, women hats precisely. In postmodem time, there is no problem with it, but what make it problem is the way he keeps them. Mrs. Crosby initially uses this as her disguise to criticise him. Yet, what the play presents further might be interpreted as a fear of Mrs. Crosby to the concept of hermaphrodite in Mr. Newbold's nature. The play depicts 
how a woman is afraid of a man having women's characietisusucs as as she (might) has. Further, it is very interesting to observe that this fear can be grasped as generally social perception within the structure of the society in the play. Mrs. Crosby may see Mr. Newbold as 'an effeminate man' or 'sissy'.

The third aspect that needs to be reinforced is about the multidimensional aspects in the play. The multi-dimensional aspects in gender study, may deal with symbols, the ethnicity, social class, race and so forth. Yet, in this analysis, the most obvious aspect of the play is the use of hat that obviously refers to a particular sex. In Inge's The Tiny Closet, the hats are culturally and socially designed to be women's accessories. It can be proven as described in the following.

(Mrs. HERGESHEIMER flutters out of the house as though wanting to avoid further involvement. MRS. CROSBY studies the hat again, taking it to the mirror to try it on. She deliberately burlesques its elegance and all that it signifies of feminine daintiness and beauty.......) (p.28)

From the above excerpt, it can be easily defined that the hats made by Mr. Crosby are women's hats. This may to some extent describe that hats, which are symbolically represent beauty, elegance and women, are used to articulate the fear of Mrs, Crosby upon feminine tendency possessed by Mr. Newbold. Another evidence pointing out at the fear of Mrs. Crosby can also be delineated as follows.

Mrs. Crosby: I don't care if he does. Just let him try to scold me, in that superior way of his. (imitating MR. NEWBOLD) "Mrs. Crosby, someone's been tampering with the lock on my closet. I demand privacy, Mrs. Crosby. That's all I ask, is just one tiny closet to call my own. That's all I ask." Hmm. I'll have an answer for him. "What in God's name does a grown-up man like you mean by making hats, Mr. Newbold? Shame!" That's what I'Il tell him. And he won't act so superior then. (p.28)

\section{CONCLUSION}

Thus, it can be stated that what so-called the fear of having the characteristic of the opposite sex is truly the very heart of the play. That Mrs. Crosby has such a fear is to be seen as cuiturally social construction. Regarding that she is a middle class white woman, the case is quite obvious to be said that it retains the polarisation of men and women as traditionally and culturally shaped. Its retaining of the polarisation lies in the representation 
of the characters from which their relationships are formed. Further, such a kind of interrelation brings about a perception that though Mr. Newbold is the protagonist, it is Mrs. Crosby who should be deconstructively perceived as the one who has the real gender problem.

\section{REFERENCES}

Budianta, Melanie. 1998. Sastra \& Ideologi Gender. Jakarta: Horrison

Curry, Dean. 1985. Plays for Reading. Washington D.C.: English Language Programs Division, Bureau of Educational and Cultural-AffairsUnited States Information Agency.

Durrant, Allan \& Fabb, Nigel, 1996. Literary Studies in Action. London \& NewYork: Routledge.

Friedan, Betty.1995. Beyond Gender. http://www.feminist.com/beyond.htm Gaunlett, David. 1998. Judith Butler(summary on Gender Trouble) http:/l www.theory.org.uk/ctr-butl.hum

Green, Keith \& LeBihan, Jill. 1996, Critical Theory and Practise: A Coursebook, London \& New York: Routledge.

Humm, Maggie. 1992. Feminism: A Reader. London \& Newyork: Harvester Wheatsheaf

Shelden, Roman \& Widdowson, Peter. 1993. A Reader's Guide to Contemporary Literary Theory. $3^{\text {nd }} \mathrm{ed}$. London and New York: Harvester Wheatsheaf) 